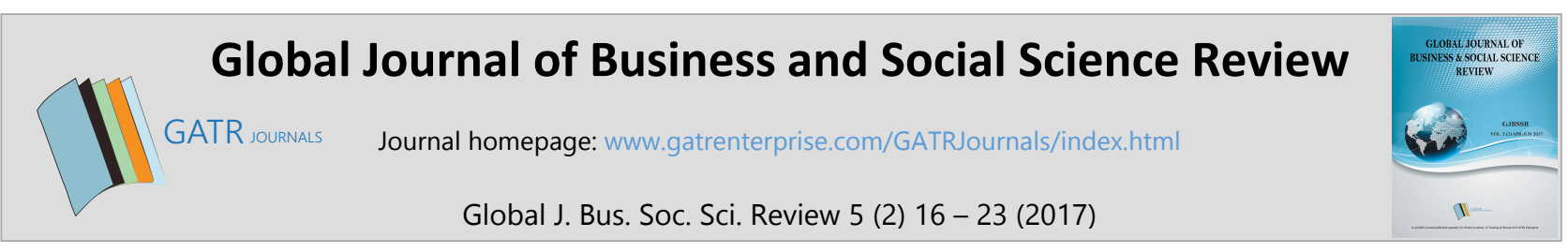

\title{
Economic Speculative Motives in Selling Relocation Houses and the Provision of Assets for Urban Settlements
}

\author{
Mulyadi ${ }^{1 *}$ and Arif Rahman Hakim ${ }^{2}$ \\ ${ }^{1,2}$ FEB Universitas Sebelas Maret, J1. Ir. Sutami No. 36 A, Kentingan, 57126, Surakarta, Indonesia
}

\begin{abstract}
Objective - This research aims to analyze the impact of residential relocation to the change in social and economic conditions of the beneficiary. This change is then used to analyze whether it is related to the decision for selling, or putting out to lease, the relocation house.

Methodology/Technique - Primary data is collected from 68 samples which are chosen by an area sampling method. The focus of the sample is on houses which are built between 2008 and 2010. The variables applied cover perception about the state of the relocation house, perceptions of change in social and economic conditions, perceptions of housing characteristics and perceptions of the existence of another residential house. This research uses a mixed method for analyzing and interpreting the results. A binary response model is used for quantitative analysis.

Findings - The results shows that there is no significant change in the social and economic conditions of the beneficiary. The logistics model indicates there is no direct correlation between perceptions of the change in social economic conditions to the decision for selling or renting a relocation house.
\end{abstract}

Novelty - The study looks at decisions for selling or renting s relocation house.

Type of Paper: Empirical.

Keywords: Relocation; Speculative Motive on Housing; Binary Respond Model.

JEL Classification: R21, R23.

\section{Introduction}

Relocation housing was developed following the major flood in 2007 of the Bengawan Solo River. Those who live along the Bengawan Solo's riverbank are often identified as a slum community. Rapid growth of assets and property in Surakarta forces certain communities to live on the riverbanks. The existence of the perceived slum situation is characterized by poor quality of housing, below minimum requirement life facilities and uncomfortable living conditions.

These condition are thought to progressively worsen. Land and house prices are likely to increase rapidly, becoming un-affordable for the sample group. The local government of Surakarta have been attempted to implement a series of programs aimed at overcoming the social problems associated with the development of this settlement. One such program is relocation, which is intended to accommodate people affected by the flooding of river.

\footnotetext{
* Paper Info: Revised: December 14, 2016

Accepted: April 25, 2017

* Corresponding author:

E-mail: mulyadi.detigampd@gmail.com

Affiliation: Fakultas Ekonomi dan Bisnis, Universitas Sebelas Maret, Indonesia.
} 
Relocation settlements in Surakarta are concentrated in the District Banjarsari Mojosongo region. This region is characterised by uneven ground contours, inadequate public facilities and poor water quality, so the price of housing is quite varied and tends to be inexpensive. This area has been selected by the local government with the following considerations; (1) the price of land is relatively cheap, (2) the area is largely undeveloped and (3) the area is available for development as a settlement area.

This program is one manifestation of the local governments' concern in providing shelter for their residents. Unfortunately, this program is still facing obstacles in relation to its implementation. Undeveloped community life patterns and mass transport facilities are not yet available. These issues certainly raise concerns for the people who are being relocated.

The question then that arises: why do the home owners commercialize their subsidized assets (the relocation house) and where do they live?. Logically there will be several choices that can be taken by those home owners. Beneficiaries of the relocation will return to their original places in order to return to the pattern of their previous lives. There is also the possibility that they will be back together with their family and ancestors. Another possibility is that they will move to another location and form a new slum community (Levy, 1985: 192).

This research focuses on the discussion surrounding the variables that determine the number of relocation houses been commercialized and whether the satisfaction level of the beneficiary affects their decision to commercialize. By understanding these variables, it will reveale the reasons behind the sale of, and commercialization of, relocation housing

\section{Literature Review}

\subsection{Relocation and Speculation}

A relocation plan is a structure used to rebuild homes and neighbourhoods and maintain productive assets, including land and public infrastructure at the site or other land. The terminology of speculation is interpreted as an attempt to sell or rent the house to gain economic benefits. If the value of the relocation house is rated higher by their owners than the market value, then the owner will likely retain their home. Conversely, if the market value is greater than expected, then there is a chance that the owner to relinquish ownership status (Fajriyanto, 2000).

\subsection{Relocation Impacts}

Social effects experienced by people affected by relocation can vary. The most prominent issue in todays' era mainly concerns the impact on health and psychology, religious life, communication between groups of immigrants to the new landowners, potential crime rates and access to education. Social system that have been built on the origin site are interrupted by the relocation program (Bennett, 2008; Louw, 2007; Cole and Flint, 2007). The economic impact of the relocation program include, for example, the loss of assets such as land and property, loss of livelihood, increases in the cost of living, the loss of employment opportunities and the issue of accessibility to the workplace (Jones and Ogilvie, 2012; Theodos and Parilla, 2010; WCD Report, 2010).

\subsection{Speculation Indicators}

There are several indicators that describe several possible intermediaries in the housing market, namely; (1) to provide profit to the intermediary. For example, intermediaries buy a home from a seller who really wants to sell his house, maintain it for a short time, and release it at a price high enough after patiently waiting for the right buyer (Fama, 1965). (2) they perform physical improvements to the home, thus retaining the availability of homes in the neighbourhood for longer priods (Fama, 1965). (3) there is a motive to gain benefit 
in the short term (Johri and Leach, 2000; Andergassen, 2003). For intermediaries this factor is a major contributor to speculation. (4) there are certain motivations from the owner of the house. Glower, Donald, and Patric (1998) state that motivation is hard to define explicitly, but the indicators are explained as other home ownership, changes in the workplace and the characteristics of the owners themselves. (5) Levels of sales/home ownership related to the environment and the attributes inherent in the home. Homeowners are not concerned with making sacrifices for the cost of home care, gardening and the environment in the long term (Glaeser and Shapiro, 2003). (6) the costs associated with renting a house. If the cost to rent the house is lower than the interest rate involved in repaying the home, then the family is more likely to sell the house (Glaeser and Shapiro, 2003; Case and Schiller, 2003).

Hsi-Fu, Wan-I, Jyh (2013) analyzed the impact of the hurricane disaster in Taiwan in 2009 on relocation. The main focus of this research was the social aspect of community solidarity post-relocation. The results of this qualitative study concluded that the relocation program has a real impact on community social solidarity.

Kortum et al. (2012) developed a model which explains the impact of socio-economic and demographic households on the decision to move residence. The estimation is conducted using household data from Florida, USA in 2009. Kortum uses micro-level models with a binary discrete choice. His study states tha: (1) the higher the quality of the relocation, the lower amount of residents pushing to find alternative residence, (2) the model estimation results indicate that some aspects of the demographic and socio-economic conditions significantly affect the decisions of households when choosing a particular residential location, (3) if the household is not satisfied with the quality of the environment, quality of schools and the proximity to employment opportunities, retail and housing, the residents will try to relocate to a more desirable location.

Lee (2012) analyzes the influence of comfortable environmental variables of housing against the decision to move from one location to another. The data used in this survey is data from between $1970-1986$ and 1991 - 2003 in the USA. The study uses multinomial logit models using displacement by combining households with the decision of choosing the status of the house. Lee mentions that environment variables have considerable influence but that the influence varies with the decision to move residence.

Kapse, Arun, and Mayank (2012) analyze the success rate of the relocation program in Nagpur India. The model is descriptive qualitative research, outlining many relocation cases in various states and comparing them with the cases of relocation that occurred in the cities of India. The results conclude that their location for relocation was ultimately unsuccessful.

\section{Research Methodology}

A quantitative method is required for the testing of information given by the respondents as primary data. Primary data is used to capture the perception of changes in economic and social conditions of beneficiaries of the relocation program. The sample size is counted using the Slovin formula; the number of the population is 268 and 68 households were selected as the samples. The sample was selected by implementing a method of area/cluster sampling with certain considerations; population distribution, characteristics of the population, and proximity (Saunders, Lewis, and Thornhill, 2009: 230).

\subsection{Validity and Reliability Testing}

Since this research uses primary data gained from questionnaires, validity and reliability testing is absolutely needed for pilot testing. The result of the reliability testing shows that all of the research questions have a score higher than the Croanbach Alpha indicator $(>0,6)$. So, all of the questions are reliable. For validity testing, the 18 question are valid because they are not higher than the Pearson Coefficient Significance $(<0.05)$. 


\subsection{Model Estimated}

Binary logistic regression is selected because there is only a dummy for independent variable (option 1 or $0)$. The models used in this study are as follows:

$\ln (\mathrm{P} /(1-\mathrm{P}))=\beta \_0+\beta \_2 \mathrm{LIKE}+\beta \_1$ PERS_EKOSOS $\beta \_3$ ATTRIB $+\beta \_4 T$ TT_ALT where:

$(\mathrm{P} /(1-\mathrm{P}))=$ dummy variable for doing speculation of relocation house (sell/ rent)

PERS_EKOSOS = perception of changes in social-economic conditions;

LIKE $^{-} \quad$ perception about attributes/ characteristics of relocation house;

TT_ALT = perception of the existence of an alternative place to live;

In the binary logistic model of R2, the regular OLS regression can not be used, therefore the degree of accuracy of the model is indicated by the coefficient McFadden R-Squared. Researcher by Gujarati (2003) suggests not to assume more important roles than this coefficient as a accuracy measure of the model when the dependent variable is a dichotomous variable. This study also uses a Hosmer-Lemeshow test to examine the fit of the model. A model is said to be a good fit if it has a probability of HL>0.05 (Suardi, 2011: 22). This study also uses white for testing heteroscedasticity and a BG/LM test for auto-correlation problems.

\section{Results}

\subsection{Changes in Social-Economic Conditions Post-Relocation}

The quality of social life in residential relocation is no better than the origin. Quality of neighboring life between new a comer (relocation's beneficiary) with local residents and environmental security problem actually rated worse than the conditions in the original neighborhood. At a glance it appears that social conditions after relocation decrease however, the "before relocation" social conditions have a score of 4.11 and the conditions after relocation is 4.10 . Thus the difference is only 0.01 . Therefore it is not possible to conclude whether a change in the social conditions is caused by the relocation program until statistical testing is conducted. The results are shown below:

Table 1. Paired Sample T Test Results Social Conditions

\begin{tabular}{|l|c|c|l|}
\hline \multicolumn{1}{|c|}{ Variable } & t & Prob. & \multicolumn{1}{c|}{ Criteria } \\
\hline $\begin{array}{l}\text { Perceptions of Social } \\
\text { Conditions }\end{array}$ & 2.857 & 0.006 & $\begin{array}{l}\text { There are significant differences in conditions } \\
\text { before and after relocation }\end{array}$ \\
\hline
\end{tabular}

Sources: Appendix 9 (processed) 2014

The public perception of economic conditions after relocation demonstrate a decline. Economic conditions prior to relocation score 4.02 which rose 0.02 to 4.04 after relocation. However, to prove this is a significant change, it needs to be proven statistically as shown below:

Table 2. Paired Sample T Test Results of Economic Conditions

\begin{tabular}{|l|c|c|l|}
\hline \multicolumn{1}{|c|}{ Variable } & t & Prob. & \multicolumn{1}{c|}{ Criteria } \\
\hline $\begin{array}{l}\text { Perceptions of Economic } \\
\text { Conditions }\end{array}$ & $-0,800$ & 0,427 & $\begin{array}{l}\text { Not significant, there was no difference in the } \\
\text { condition before and after relocation }\end{array}$ \\
\hline
\end{tabular}

Sources: Appendix 9 (processed) 2014 


\subsection{Speculative Motive for Selling Relocation House}

The appropriate model for estimating the effect of the independent variables on the decision to transfer the house to a relocation house is a binary response model; the logit or probit. Below is a comparison of the results of the regression using the logit and probit:

Table 3. Comparison of Logit and Probit Regression Results

\begin{tabular}{|l|c|r|r|r|}
\hline \multirow{2}{*}{ Variable } & \multicolumn{2}{|c|}{ Logit Reg. } & \multicolumn{2}{c|}{ Probit Reg. } \\
\cline { 2 - 5 } & $\boldsymbol{\beta}$ & Prob. & $\boldsymbol{\beta}$ & Prob. \\
\hline LIKE & -3.1379 & 0.0017 & -3.2813 & 0.0010 \\
\hline ATTRIB & -1.4337 & 0.1516 & -1.4598 & 0.1443 \\
\hline ALT & 2.8290 & 0.0047 & 2.9903 & 0.0028 \\
\hline EKO_SOS & -0.7894 & 0.4298 & -0.7274 & 0.4669 \\
\hline McFadden R-squared & & 0.363935 & & 0.370265 \\
\hline Log likelihood & & -29.51088 & & -29.21722 \\
\hline Prob. (LR Statistic) & & 0.000001 & & 0.000001 \\
\hline
\end{tabular}

Sources: Appendix 10 (processed) 2014

Considering the large coefficient of the log-likelihood and McFadden R-squared, the probit model is superior to the logit model. This is because the McFadden R-squared coefficient in the probit model is 37.02 percent which is higher than the logit model. The coefficient of the log-likelihood probit model is -29.21> which is also higher than logit model coefficients. Therefore, the model chosen is the probit models. Thus, the model that is interpreted both statistically and economically is the probit model.

\subsection{Test Results of the Z-Statistic (Partially Significant)}

Significant coefficients generated from the results of the testing are summarized as follows:

Table 4. Partial Significance Test Results

\begin{tabular}{|l|c|c|l|}
\hline \multicolumn{1}{|c|}{ Variable } & Prob & $\boldsymbol{\alpha}$ & \multicolumn{1}{c|}{ Criteria } \\
\hline EKO_SOS & 0.4298 & 0,05 & not significant \\
\hline LIKE & 0.0017 & 0,05 & significant \\
\hline ATTRIB & 0.1516 & 0,05 & not significant \\
\hline ALT & 0.0047 & 0,05 & significant \\
\hline
\end{tabular}

Sources: Appendix10 (processed) 2014

\subsection{LR Test Results Test - Likelihood Ratio Statistics}

The probit value of the LR Statistics is estimated at 0.000001 and the figure is less than the real degree $(\alpha)$ of 0.05 , so $\mathrm{H} 1$ is rejected. Thus, the real variables in the model both significantly affect the dependent variable. All variables simultaneously significantly influence the decision of commercializeing relocation houses, even where the variables EKO_SOS and ATTRIB are partially not significant.

\subsection{The Test Results and the Fit of the Determination Coefficient}

The McFadden R-Squared value obtained from the test is equal to 0.370265 . This number shows that 37.02 percent of the model in this study could explain the case of commercializing the relocation house, while the 
remainder is explained by variables which is not included in the model. A McFadden R-Squared index of 37.02 percent indicates that the model is a good fit for a binary response analysis. The quality of the model used in this study was also tested using the Hosmer and Lemeshow Goodness of fit test, to predict observed values matched with the data observations. The value of Hosmer and Lemeshow Goodness of fit test is $0.7482>0.05$. Therefore, the model is appropriate to explain the issue of selling a relocation relocation house and speculation.

\subsection{Hypotheses Testing (Econometric Testing)}

Test results for multicollinearity problem in this study are as follows:

Table 5. Correlation Coefficient between the Independent variables

\begin{tabular}{|c|c|c|c|c|}
\hline & LOG(EKO_SOS) & LOG(ALT) & LOG(ATTRIB) & LOG(LIKE) \\
\hline LOG(EKO_SOS) & 1.000000 & -0.004357 & 0.100598 & 0.075807 \\
\hline LOG(ALT) & -0.004357 & 1.000000 & -0.133310 & -0.191334 \\
\hline LOG(ATTRIB) & 0.100598 & -0.133310 & 1.000000 & 0.050780 \\
\hline LOG(LIKE) & 0.075807 & -0.191334 & 0.050780 & 1.000000 \\
\hline
\end{tabular}

Sources: Appendix11 (processed) 2014

The index of correlation between all variables is less than 0.85 , thus it can be concluded that the model in this study is free from multicollinearity problems. The Heteroscedasticity test using the method of the White test results are as follows:

Table 6. Heteroskedasticity Testing: White test

\begin{tabular}{|l|r|l|r|}
\hline F-statistic & 2.435197 & Prob. F(14,53) & 0.0101 \\
\hline Obs*R-squared & 26.61883 & Prob. Chi-Square(14) & 0.0216 \\
\hline Scaled explained SS & 8.992018 & Prob. Chi-Square(14) & 0.8316 \\
\hline
\end{tabular}

Sources: Appendix 12(processed), 2014

The Chi-Square probability value obtained is equal to $0.0216<\alpha 0.05$, which is a significant indikator that $\mathrm{H} 1$ is accepted. In conclusion, there was indeed a problem of heteroscedastisity. Thus, the healing requires the white method. The results are as follows:

Table 7. Summary White Heteroscedasticity-Consistent Standard Errors \&Covariance

\begin{tabular}{|l|c|c|c|c|}
\hline \multirow{2}{*}{ Var. } & \multicolumn{2}{r|}{ Before } & \multicolumn{2}{c|}{ After } \\
\cline { 2 - 5 } & Std. error & Prob. & Std. error & Prob. \\
\hline C & 0.577989 & 0.0663 & 0.512149 & 0.0389 \\
\hline EKO_SOS & 0.009823 & 0.5588 & 0.010133 & 0.5709 \\
\hline ATTRIB & 0.015761 & 0.2602 & 0.016046 & 0.2687 \\
\hline ALT & 0.046007 & 0.0012 & 0.034920 & 0.0000 \\
\hline LIKE & 0.032588 & 0.0002 & 0.024921 & 0.0000 \\
\hline
\end{tabular}

Sources: Appendix (processed) 2013

Repairing heteroscedasticity problems based on Table 7 resulted in a more efficient error value. The next test is the residual auto correlation problem. This study uses the method of the Breusch-Godfrey (BG)/Lagrange Multiplier (LM Test). The results are as follows: 
Table 8. Breusch-Godfrey Serial Correlation LM Test

\begin{tabular}{|l|l|l|l|}
\hline F-statistic & 0.746857 & Prob. F(2,61) & 0.4781 \\
\hline Obs*R-squared & 1.625323 & Prob. Chi-Square(2) & 0.4437 \\
\hline
\end{tabular}

Sources: Appendix 13 (processed) 2013

The Chi-Square probability value obtained is equal to $0.4437>0.05$ which is not significant of $(\alpha)$ and therefore, $\mathrm{H} 1$ is accepted. In conclusion, there is no problem of auto-correlation.

\subsection{Economic Interpretation}

The results of the regression potential for speculation with the independent variables in this study are presented in the following equation:

SPECULATION $=2.848407+0.593804 *$ LIKE $+0.089662 *$ ATTRIB $+0.726473 *$ ALT +
$0.0270936 *$ EKO_SOS

Perceptions of economic and social change have a negative coefficient which can be decoded for the lower change in social-economic conditions causing a higher probability that home owners will transfer their relocation houses. The findings in this study are in line with the research hypothesis. Variable satisfaction/ease of relocation has a negative impact on the possibility of commercializeing the relocation house. This is also in accordance with the research hypothesis. Furthermore, variables of house attributes have a negative coefficient. This means that a better perception by the occupants of the characteristics of the relocation home by as little as 1 percent, will decrease the chances of commercializing the house by 0.09 percent.

The variable perception of the existence of an alternative place to stay has a positive and significant coefficient at the rate of 0.72 . This means that a 1 percent increase in this variable would increase the tendency to transfer the relocation home by 0.72 percent. This variable supports the hypothesis which states that the perception of the existence of other alternative means of shelter will have a positive impact.

\section{Discussion and Conclusion}

The first reason behind the commercialization of a relocation house is internal issues concerning e.g. household economic conditions relating to debts, the relationship between household members and characteristics of household members. The internal problems of households in this study were obtained through in-depth interviews. The second factor leading to the commercialization of relocation homes is the motive of making a profit despite the unethical nature of this decision. This factor has not been incorporated into the model for quantitative testing, but was identified as the cause of many cases of housing speculation (Leach Johri, 2000; Andergassen, 2003).

The third factor is the issue of household debt. Home owners' relocation is often saddled with debt which is used to renovate their homes. If the household struggles to repay this debt, they may be more likely to choose to sell the house. Quantitative analysis states that this factor will only be a significant variable in unison testing.

Based on the result of in-depth interviews, group discussions and quantitative testing, it was concluded that the variables which influence the decision to sell or rent a relocation house are; characteristic factors of the house, social-economic conditions and the incorrect motivation for potential benefit. Therefore, the issue of commercializing relocation houses is not solely caused by changes in economic conditions. There are also other ethical and law enforcement which have not been established in this study. 


\section{References}

Andergassen, R. (2003). Rational destabilising speculation and the riding of bubbles. Working Papers 475, Universita di Bologna. Retrieved from: www2.dse.unibo.it/wp/475.pdf

Bennett, C. (2008). Relocation, Relocation: The impact of internal relocation on women asylum seeker. Asylum Aid: London, England. Retrieved from: www.asylumaid.org.uk/wpcontent/uploads/2013/02/Executive_Summary.pdf

Case, K. E., \& Shiller, R. J. (1988). The efficiency of the market for single-family homes. The American Economic Review 79. 125-137.

Cole, I., \& Flint, J. (2007). Demolition, Relocation and Affordable Rehousing: Lessons from the Housing Market Renewal Pathfinders. Sheffield Hallam University and Joseph Rowntree Foundation Publication: United Kingdom. Retrieved from: www.jrf.org.uk/sites/files/jrf/1965-demolition-relocation-rehousing.pdf

Fajriyanto (2000). Pembangunan Perumahan Ditinjau dari Aspek Spekulasi Studi Kasus pada Perumahan di Yogyakarta. Jogjakarta.

Fama, E. F. (1965). The behavior of stock-market prices. The journal of Business, 38(1), 34-105.

Glaeser, E. L., \& Shapiro, J. M. (2003). The benefits of the home mortgage interest deduction. Tax policy and the economy, 17, 37-82.

Glower, M., Haurin, D. R., \& Hendershott, P. H. (1998). Selling time and selling price: The influence of seller motivation. Real estate economics, 26(4), 719-740. USA. Retrieved from: www.areuea.org/publications/ree/articles/V26/R-EE.V26.4.7.PDF

Gujarati, D.N. (2003). Basic Econometrics Fourth Edition.McGraw-Hill International Edition: Singapore

Fu, T. H., Lin, W. I., \& Shieh, J. C. (2013, January). The impact of post-disaster relocation on community solidarity: The case of post-disaster reconstruction after Typhoon Morakot in Taiwan. Journal World Academy of Science, Engineering and Technology 78(30) ed 2013. Retrieved from: www.taiwan921.lib.ntu.edu.tw/mypdf/mypaper30A.pdf

Johri, A., \& Leach, J. (2002). Middlemen and the allocation of heterogeneous goods. International Economic Review, $347-361$.

Jones, C. H., \& Ogilvie, D. (2012). Motivations for active commuting: a qualitative investigation of the period of home or work relocation. International Journal of Behavioral Nutrition and Physical Activity, 9(1), 109.

Kapse, V., Pofale, A., \& Mathur, M. (2012). Paradigm of relocation of urban poor habitats (slums): case study of Nagpur city. Int J Soc Behav Educ Econ Bus Ind Eng, 6, 2916-2923.

Kortum, K., Paleti, R., Bhat, C., \& Pendyala, R. (2012). Joint model of residential relocation choice and underlying causal factors. Transportation Research Record: Journal of the Transportation Research Board, (2303), 28-37.

Lee, K. O. (2012). Residential Relocation Decisions: The Role of Neighborhood Housing Characteristics. IRES Working Paper Series. Retrieved from: www.ires.nus.edu.sg/workingpapers/IRES2012-012.pdf

Louw, A. (2007). Relocated Squatters Want to Go Home. The Star Newspaper: Ekurhuleni Edition. South Africa. Retrieved from: http://www.kzndhs.gov.za/Portals/0/docs/publications/clippings/23march2007g.pdf

Saunders, M., Lewis P., \& Thornhill A. (2009). Research Methods for Business Students Fifth Edition. Prentice-Hall: England

Theodos, B. \& Parilla, J. (2010). Relocating Vulnerable Public Housing Families. Urban Institute Publication: Washington, USA.http://www.urban.org/uploadedpdf/412258-Relocating-Vulnerable-Public-Housing-Families.pdf

WCD Report. (2010). Dam's Impact and Effectiveness. Asean Development Bank. Retrieved from: www.forum-adb.org 